\title{
IAMJ
}

INTERNATIONAL

AYURVEDIC

MEDICAL JOURNAL

\section{EVALUATION OF NEPHROPROTECTIVE ACTIVITY OF KATAKABEEJA YOGA AGAINST ASPIRIN-INDUCED NEPHROTOXICITY IN WISTAR RATS}

\author{
Manohar S. Sarangi ${ }^{1}$, S. K. Hiremath ${ }^{2}$, Girish Danappagoudar ${ }^{3}$, Basavaraj Mulkipatil ${ }^{4}$ \\ ${ }^{1}$ Associate Professor, Department of Agada Tantra, Shri Veerpulikeshi Rural Ayurvedic Medical College Hospital \\ and Research Center, Badami - 587201, Karnataka, India \\ ${ }^{2}$ Professor \& HOD, Department of Agada Tantra, DGM Ayurvedic Medical College Hospital and Research \\ Center, Gadag, Karnataka, India \\ ${ }^{3}$ Professor \& HOD, Department of Rasashastra, Shri Veerpulikeshi Rural Ayurvedic Medical College Hospital \\ and Research Center, Badami - 587201, Karnataka, India \\ ${ }^{4}$ Principal, Professor \& HOD, Department of Kayachikitsa, Shri Veerpulikeshi Rural Ayurvedic Medical College \\ Hospital and Research Center, Badami - 587201, Karnataka, India
}

\section{Corresponding Author: manusarangi27@gmail.com}

\section{https://doi.org/10.46607/iamj08p6012021}

(Published online: November 2021)

Open Access

(C) International Ayurvedic Medical Journal, India 2021

Article Received: 21/10/2021 - Peer Reviewed: 27/11/2021 - Accepted for Publication: 30/11/2021

Check for updates

\section{ABSTRACT}

Drug-induced toxicity is the major concern in the present Era, particularly with Hepato and Nephrotoxicity. Druginduced renal failure (RF) accounted for $20 \%$ in India. As there is an increasing number of potent therapeutics drugs like - NSAID's (Aspirin), Antibiotics, chemotherapy agents etc. Katakabeeja Yoga is mainly indicated in Prameha Chikitsa according to Yogaratnakar. Kataka (Strychnos potatorum. Linn) is Vishaghna, Ashmari, Prameha, Visha etc. Kataka - Independently have potent Antioxidant, Osmotic diuretic activity. Hence the present study was aimed to evaluate the Nephroprotective activity of Katakabeeja Yoga against Aspirin-induced Nephrotoxicity in Wistar rats. Katakabeeja Yoga was prepared after authenticating procured raw drugs and analyzed for preliminary physicochemical, organic and inorganic tests. Either sex Wistar rats weighing $150-200 \mathrm{~g}$ were selected and randomized into three groups (each group 6 no.) like Normal, Aspirin-induced, or Katakabeeja Yoga 
treated. Toxicity with Aspirin $100 \mathrm{mg} / \mathrm{kg}$ orally for 15 days. In the treated group Katakabeeja yoga $0.216 \mathrm{~g}$ (216mg) was received after administration of Aspirin for 15 days and sacrificed on the $16^{\text {th }}$ day. Before and end of the study, the blood sample was collected for estimation of biomarkers like Serum Creatinine, urea and electrolytes. The kidney was kept in a $10 \%$ formalin solution and sent for histopathology studies. Data were analyzed by one way ANOVA and Tukey's multiple post hoc procedures. The Aspirin group showed a significant rise in serum Creatinine, and urea followed by a decrease the urine output. Katakabeeja Yoga significantly reduced the serum Creatinine and urea followed by an increase in the urine output may have Katakabeeja potent antioxidant, osmotic diuretic activity. The study established that Katakabeeja Yoga possesses a durable Nephroprotective effect against Aspirin-induced Nephrotoxicity.

Keywords: Nephroprotective, Kataka, Nephrotoxicity

\section{INTRODUCTION}

Drug-induced toxicity is the major concern in the present Era, particularly with Hepato and Nephrotoxicity. There is an increasing number of potent therapeutic drugs like Aminoglycosides, Antibiotics, NSAID's (Ibuprofen, Indomethacin, Aspirinetc.). ${ }^{[1]}$

Oxidative damage is possibly an important mechanism in the pathogenesis of Aspirin nephrotoxicity. It was reported that Aspirin exerts nephrotoxicity through a reduction in the production of antioxidants [2].

Inhibition of the synthesis of renal prostaglandins by NSAIDs (Aspirin) may affect renal function. The mechanism involves inhibition of vasodilator prostaglandin synthesis from arachidonic acid which leads to vasoconstriction and a decrease in glomerular capillary pressure, resulting in a prompt decline in glomerular filtration rate. This form of renal failure, which is characterized by increased serum levels of Creatinine, urea and potassium, is often sudden and is completely reversible with prompt discontinuation of NSAID. When unopposed, this may lead to acute tubular necrosis (ATN), which can also result in ARF [3].

In our classics explained Garavisha is intentionally in the olden days then unintentionally now. It is a condition explained by Acharaya which arises due to the entry of visa which has been fabricated due to a mixture of non-poisons or poisonous substances or medicines like bhasma's. When a person is exposed to these kinds of poisons, maybe for one time or longer duration, depending on the potency and nature of the poison exposed or after a long interval suffer from several disorders as per the affinity of poisons exposed ${ }^{[4]}$.

The formulation Katakabeeja Yoga is explained in the context of Prameha ${ }^{[5]}$. The chief component of this formulation is Kataka.

Kataka (Strychnos Potatorum. Linn) is explained under Vishaghna Dashamani's ${ }^{[6]}$ and used in Ashmari ${ }^{\text {[7] }}$, Visha, and Prameha ${ }^{\text {[5] }}$ etc. Kataka has reported potent antioxidant, Osmotic diuretic activity etc.

Aims and Objectives - To evaluate the Nephroprotective activity of Katakabeeja Yoga against Aspirininduced Nephrotoxicity in Wistar rats.

\section{Material and Methods:}

The study was conducted after obtaining the approval of the Institutional Animal Ethics Committee (BMK/IAEC/Res-02/2014).

\section{Animals:}

18 Healthy sex Wistar rats weighing between 150$200 \mathrm{~g}$ were used in the study. They were housed individually, and they were provided with standard feeds and water ad libitum during the experimental study (CPCSEA Guidelines). All Experimental rats were kept at an ambient temperature of $25^{\circ} \mathrm{C} \pm 5^{\circ} \mathrm{C}$ and $45-55 \%$ relative humidity with $12 \mathrm{hr}$ natural light and dark cycle.

\section{Study Design:}

The animals were randomly allocated into three groups of six animals each. Group-I control (Distilled water), Group-II Aspirin 100mg/kg/orally daily [3] and Group-III Katakabeeja Yoga. 


\begin{tabular}{|l|l|l|l|}
\hline Groups & No. of Animals in groups & Dose & Duration \\
\hline Group A & $\mathrm{n}=6$ & Control group & 15 days \\
\hline Group B & $\mathrm{n}=6$ & Aspirin 100mg/kg/orally & 15 days \\
\hline Group C & $\mathrm{n}=6$ & Katakabeeja yoga $(216 \mathrm{mg} / 200 \mathrm{~g})+$ Aspirin $100 \mathrm{mg} / \mathrm{kg} /$ orally & 15 days \\
\hline
\end{tabular}

PARAMETERS OF EXPERIMENTAL STUDY: Effect of Katakabeeja Yoga in Aspirin-induced nephrotoxicity in Wistar Rats

i. General observation- Animals of all groups were observed for their food intake and water intake, general activity, body weight, urine output throughout the experimental study.

ii. Blood investigation- $1^{\text {st }}, 8^{\text {th }}$ and $15^{\text {th }}$ day all animals were kept under observation for 24 hours. On $16^{\text {th }}$ the day animals were anaesthetized by Diethyl Ether and blood was drawn through the retro-orbital region by pricking microcapillary tube number 100 $\mathrm{mm}$ (Borosilicate glass with both ends open) and collected in labelled vials. Blood was sent to Jeevan Diagnostic Center, Belgavi for biochemical investigations.
Biochemical investigations: Blood was collected in a plain vial and subjected to performing biochemical parameters like Serum Creatinine, Serum urea, and Serum electrolyte.

iii. Histopathological investigations- Kidney was collected immediately after sacrificing by anaesthesia with diethyl ether and cleaned of extraneous tissue and transferred to $10 \%$ formalin solution in separate labelled containers sent for Jeevan Diagnostic Laboratory, Belgavi for Histopathological study.

\section{STATISTICAL ANALYSIS}

All results are expressed as the mean \pm SD. One way ANOVA was applied for testing the significant difference between three groups at each time point. Tukeys multiple post hoc procedures were applied to see the significant difference between pairs of two groups.

\section{RESULTS:}

Table 1: Statistical interpretation of SERUM CREATININE at the confidence level of $95 \%(\mathrm{p}<0.05)$ SERUM CREATININE

\begin{tabular}{|l|l|l|l|}
\hline & Normal & Aspirin & Aspirin + Katakabeeja Yoga \\
\hline Mean \pm SD & $0.9528 \pm 0.08970$ & $1.758 \pm 0.2157$ & $1.153 \pm 0.1428$ \\
\hline Significance & - & - & $* *$ \\
\hline \multicolumn{2}{|c|}{ P-VALUE } & $<2.10$ \\
\hline
\end{tabular}

Note: $* p<0.05$

Pairwise comparisons of three groups by Tukey's HSD

\begin{tabular}{|l|l|}
\hline GROUPS & SERUM CREATININE \\
\hline C vs AKY (P Value) & $<0.0001^{* * *}$ \\
\hline C Vs A (P Value) & $0.0150^{* *}$ \\
\hline AKY Vs A (P Value) & $0.0020^{* *}$ \\
\hline${ }_{p}<0.05$ & \\
\hline
\end{tabular}


Table 2: Statistical interpretation of SERUM CHLORIDE at the confidence level of $95 \%(\mathrm{p}<0.05)$ SERUM CHLORIDE

\begin{tabular}{|c|c|c|c|}
\hline & Normal & Aspirin & Aspirin+Katakabeeja Yoga \\
\hline Mean $\pm \mathrm{SD}$ & $105.3 \pm 1.748$ & $108.1 \pm 2.968$ & $107.9 \pm 2.605$ \\
\hline Significance & - & - & $* *$ \\
\hline \multicolumn{3}{|c|}{ P-VALUE } & 0.0083 \\
\hline \multicolumn{2}{|r|}{$\mathrm{F}$} & 8.720 & \\
\hline
\end{tabular}

Note: $* p<0.05$

Pairwise comparisons of three groups by Tukey's HSD

\begin{tabular}{l|l}
\hline GROUPS & SERUM CHLORIDE \\
\hline C vs AKY (P Value) & $0.0166^{* *}$ \\
\hline C Vs A (P Value) & $0.0407^{* *}$ \\
\hline AKY Vs A (P Value) & $0.9899(\mathrm{NS})$ \\
\hline
\end{tabular}

$*_{p}<0.05$

Table 3: Statistical interpretation of SERUM POTASSIUM at the confidence level of $95 \%(\mathrm{p}<0.05)$

SERUM POTASSIUM

\begin{tabular}{|l|l|l|l|}
\hline & Normal & Aspirin & Aspirin+Katakabeeja Yoga \\
\hline Mean \pm SD & $5.717 \pm 0.2765$ & $7.475 \pm 0.4311$ & $6.897 \pm 0.2444$ \\
\hline Significance & - & - & $* * *$ \\
\hline P-VALUE & 0.0002 & \\
\hline F & 35.68 & \\
\hline
\end{tabular}

Note: $* p<0.05$

Pairwise comparisons of three groups by Tukey's HSD

\begin{tabular}{|l|l|}
\hline GROUPS & SERUM POTASSIUM \\
\hline C vs AKY (P Value) & $0.0026^{* *}$ \\
\hline C vs A (P Value) & $0.0031^{* *}$ \\
\hline AKY vs A (P Value) & $0.0538(\mathrm{NS})$ \\
\hline$*_{p}<0.05$ & \\
\hline
\end{tabular}

Table 4: Statistical interpretation of SERUM UREA at the confidence level of $95 \%(\mathrm{p}<0.05)$ SERUM UREA

\begin{tabular}{|l|l|l|l|}
\hline & Normal & Aspirin & Aspirin+Katakabeeja Yoga \\
\hline Mean \pm SD & $37.44 \pm 2.834$ & $49.47 \pm 4.024$ & $43.28 \pm 3.862$ \\
\hline Significance & - & - & $* *$ \\
\hline P-VALUE & 0.0019 & \\
\hline F & 17.22 & \\
\hline
\end{tabular}

Note: $* p<0.05$

Pairwise comparisons of three groups by Tukey's HSD

GROUPS

$\mathrm{C}$ vs AKY (P Value)

$\mathrm{C}$ vs A (P Value)

AKY vs A (P Value)

$* p<0.05$
SERUM UREA

$0.0117^{*}$

$0.0383^{*}$

$0.0456^{*}$ 
Table 5: Statistical interpretation of SERUM SODIUM at the confidence level of $95 \%(\mathrm{p}<0.05)$ SERUM SODIUM

\begin{tabular}{|c|c|c|c|}
\hline 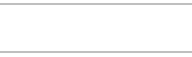 & Normal & Aspirin & Aspirin+Katakabeeja Yoga \\
\hline Mean \pm SD & $141.4 \pm 2.172$ & $148.5 \pm 1.792$ & $149.1 \pm 2.417$ \\
\hline Significance & - & - & $* * *$ \\
\hline \multicolumn{3}{|c|}{$\mathrm{P}$ value } & \\
\hline \multicolumn{2}{|r|}{$\mathrm{F}$} & 22.30 & \\
\hline
\end{tabular}

Note: $* p<0.05$

Pairwise comparisons of three groups by Tukey's HSD

\begin{tabular}{|l|l|}
\hline GROUPS & SERUM SODIUM \\
\hline C vs AKY (P Value) & $0.0115^{*}$ \\
\hline C vs A (P Value) & $0.0011^{* *}$ \\
\hline AKY vs A (P Value) & $0.8970(\mathrm{NS})$ \\
\hline
\end{tabular}

$*_{p}<0.05$

Table 6: Statistical interpretation of URINE OUTPUT $1^{\mathrm{ST}}$ DAY at the confidence level of $95 \%(\mathrm{p}<0.05)$ URINE OUTPUT $1^{\text {ST }}$ DAY

\begin{tabular}{|l|c|c|c|}
\hline & Normal & Aspirin & Aspirin+Katakabeeja Yoga \\
\hline Mean \pm SD & $4.467 \pm 1.638$ & $3.400 \pm .09716$ & $4.833 \pm 1.169$ \\
\hline Significance & P value & 0.1136 & \\
\hline & F & 3.107 & \\
\hline
\end{tabular}

Note: $* p<0.05$

Pairwise comparisons of three groups by Tukey's HSD

\begin{tabular}{|l|l|}
\hline GROUPS & URINE OUTPUT 1 ${ }^{\text {ST }}$ DAY \\
\hline C vs AKY (P Value) & 0.1819 \\
\hline C Vs A (P Value) & 0.8823 \\
\hline AKY Vs A (P Value) & 0.0708 \\
\hline
\end{tabular}

$*_{p}<0.05$

Table 7: Statistical interpretation of URINE OUTPUT $8^{\mathrm{TH}}$ DAY at the confidence level of $95 \%(\mathrm{p}<0.05)$ URINE OUTPUT $8^{\text {th }}$ DAY

\begin{tabular}{|l|c|c|c|}
\hline & Normal & Aspirin & Aspirin+Katakabeeja Yoga \\
\hline Mean \pm SD & $5.367 \pm 1.274$ & $3.383 \pm 0.8565$ & $7.733 \pm 1.108$ \\
\hline Significance & P value & 0.0032 & \\
\hline & F & 22.90 & \\
\hline
\end{tabular}

Note: $* p<0.05$

Pairwise comparisons of three groups by Tukey's HSD

\begin{tabular}{|l|l|}
\hline GROUPS & URINE OUTPUT $8^{\text {TH }}$ DAY \\
\hline C vs AKY (P Value) & $0.1274(\mathrm{~ns})$ \\
\hline C Vs A (P Value) & $0.0006^{* * *}$ \\
\hline AKY Vs A (P Value) & $0.0039^{* *}$ \\
\hline
\end{tabular}
${ }^{*} p<0.05$ 
Table 8: Statistical interpretation of URINE OUTPUT $15^{\text {th }}$ DAY at the confidence level of $95 \%(\mathrm{p}<0.05)$ URINE OUTPUT $15^{\text {th }}$ DAY

\begin{tabular}{|l|c|c|c|}
\hline & Normal & Aspirin & Aspirin+Katakabeeja Yoga \\
\hline Mean \pm SD & $6.783 \pm 0.8998$ & $2.100 \pm 1.661$ & $6.950 \pm 3.505$ \\
\hline Significance & P value & 0.0081 & \\
\hline & F & 10.23 & \\
\hline
\end{tabular}

Note: $* p<0.05$

Pairwise comparisons of three groups by Tukey's HSD

\begin{tabular}{|l|l|}
\hline GROUPS & URINE OUTPUT $15^{\mathrm{TH}}$ DAY \\
\hline C vs AKY (P Value) & 0.0087 \\
\hline C Vs A (P Value) & 0.9929 \\
\hline AKY Vs A (P Value) & 0.0227 \\
\hline
\end{tabular}

$* p<0.05$

HISTO - PATHOLOGY OF KIDNEY:

\begin{tabular}{|l|l|l|l|l|}
\hline Sl.No. & Microscopy & Normal & Aspirin & Katakabeeja yoga + Aspirin \\
\hline 1 & Tubular congestion & ++ & +++ & ++ \\
\hline 2 & Loss of Brush Border & - & + & + \\
\hline 3 & Cytoplasmic Vacuoles & - & + & - \\
\hline 4 & Tubular Necrosis & - & + & + \\
\hline 5 & Glomerular congestion & ++ & ++ & ++ \\
\hline 6 & Interstitial oedema & - & + & - \\
\hline 7 & Interstitial Haemorrhage & - & ++ & + \\
\hline 8 & Peritubular inflammation & - & +++ & + \\
\hline
\end{tabular}

(Note: + - Mild, ++ - Moderate, +++ - Severe)

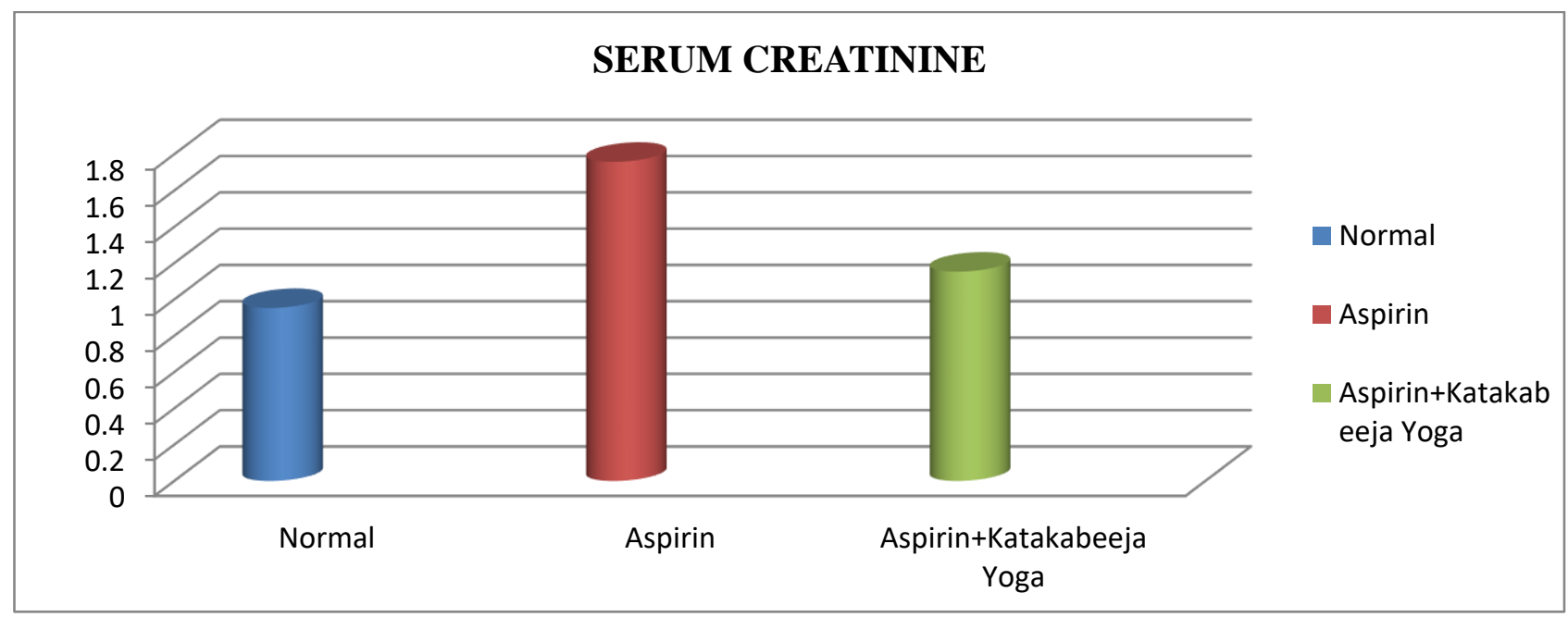



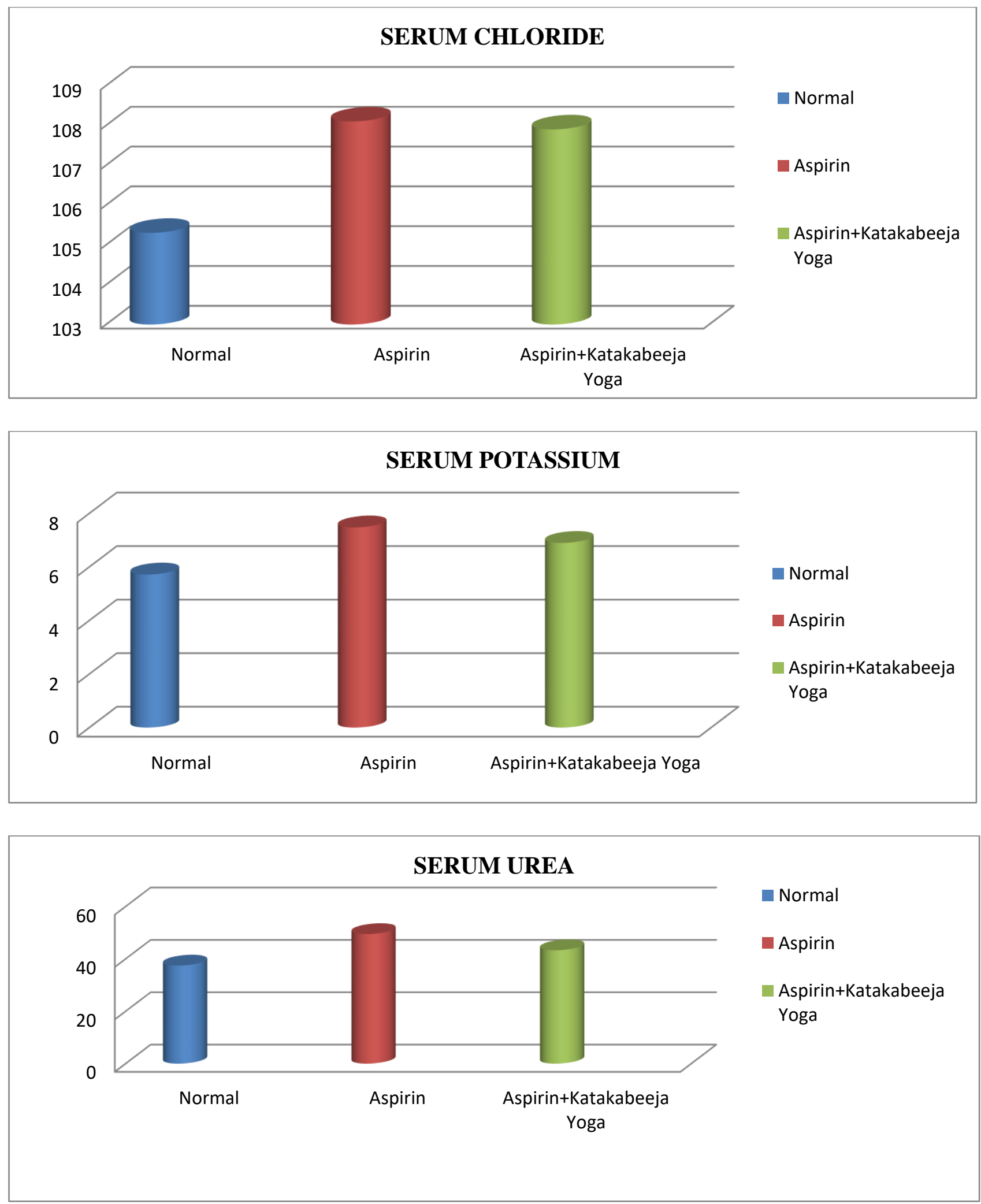

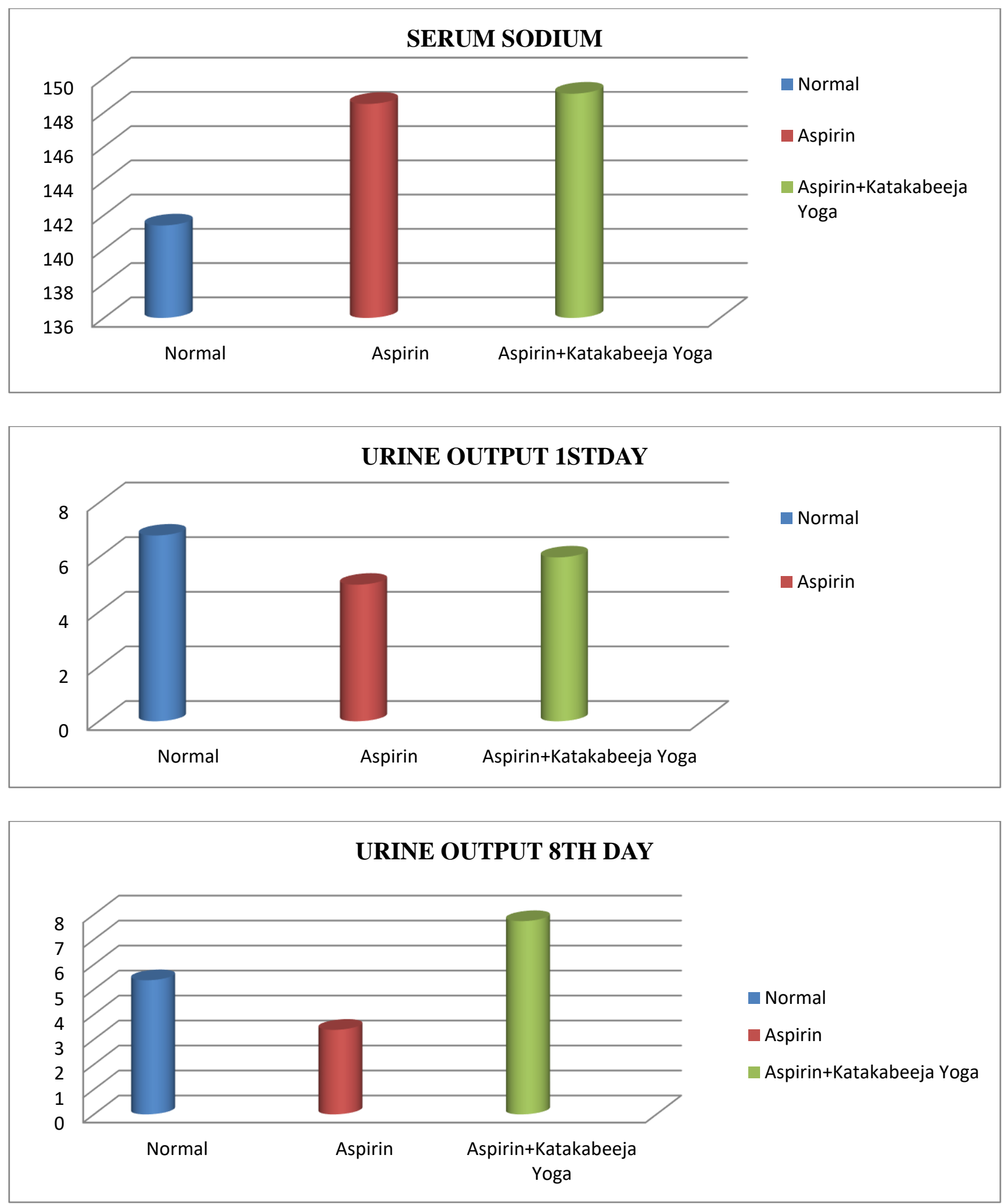


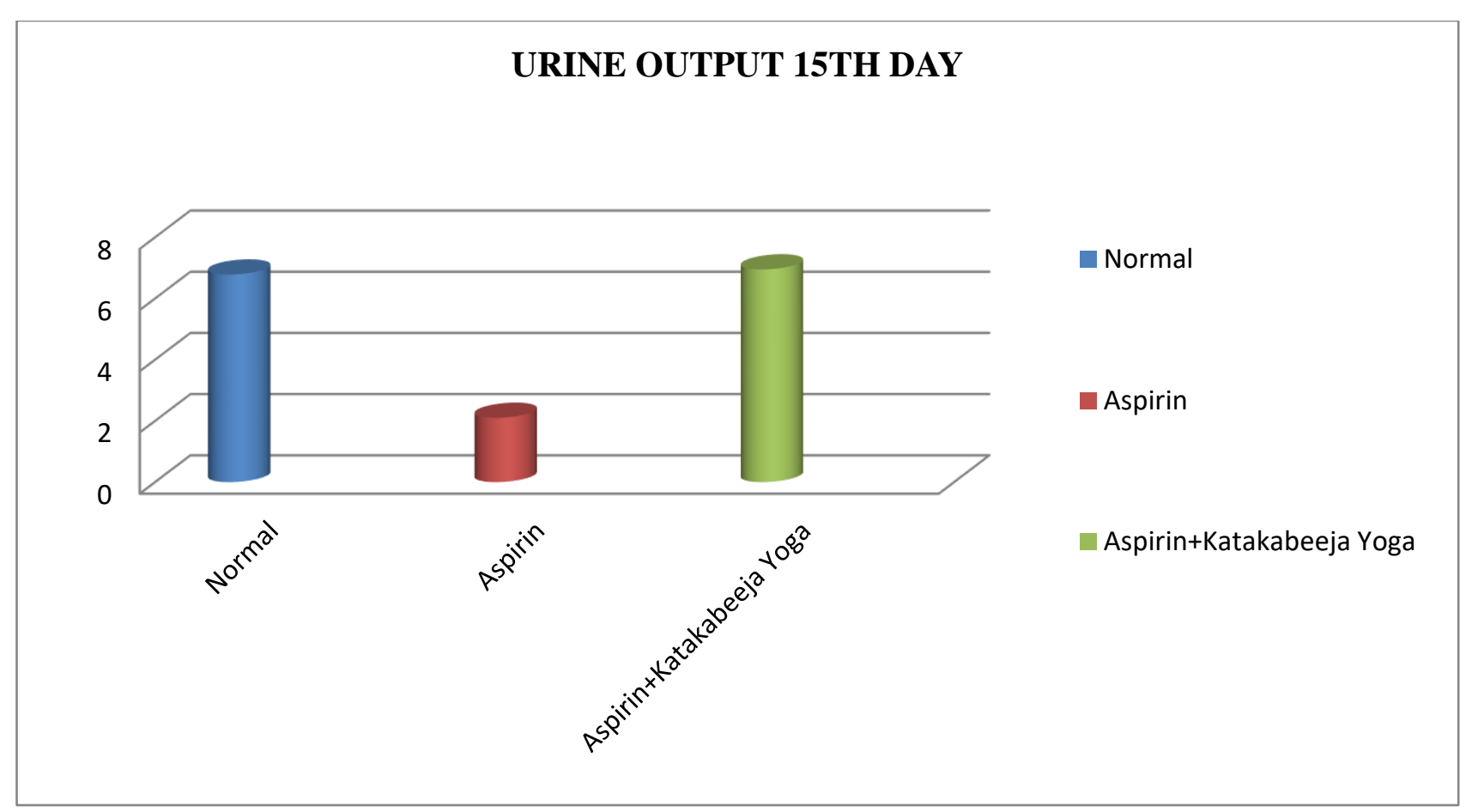

Group A - Control (40 X)
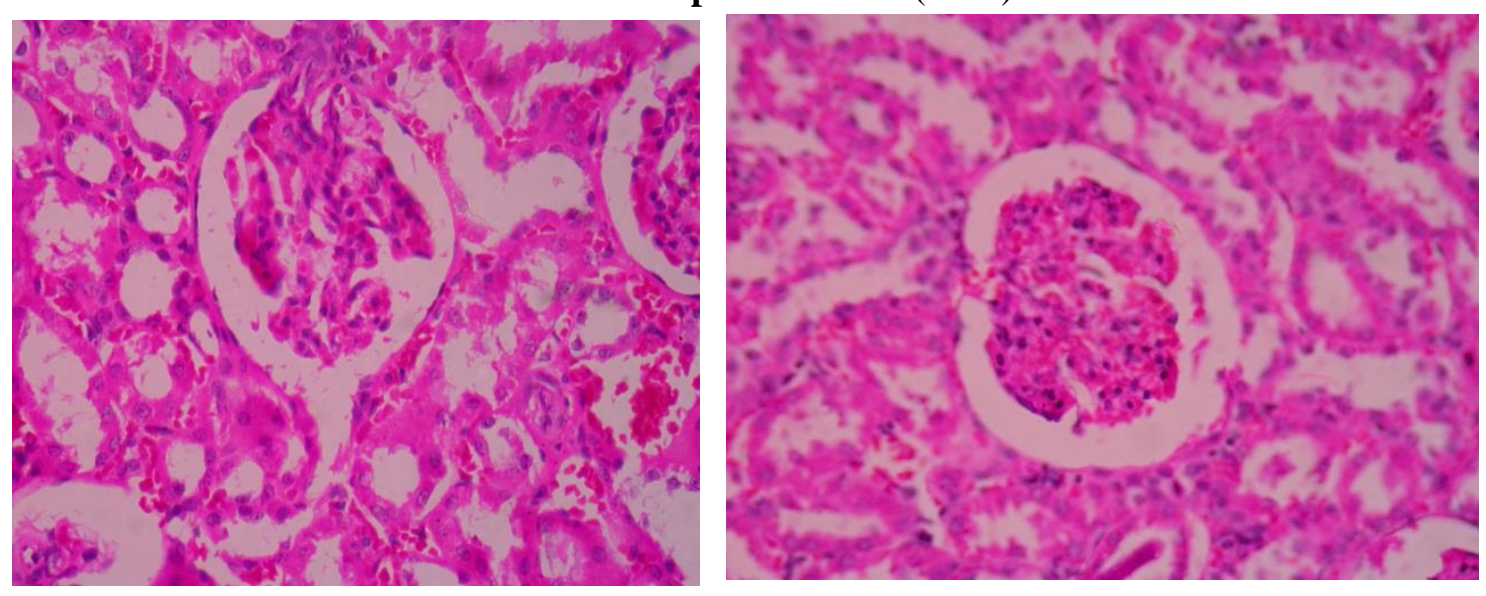

Group B - Aspirin (40 X)
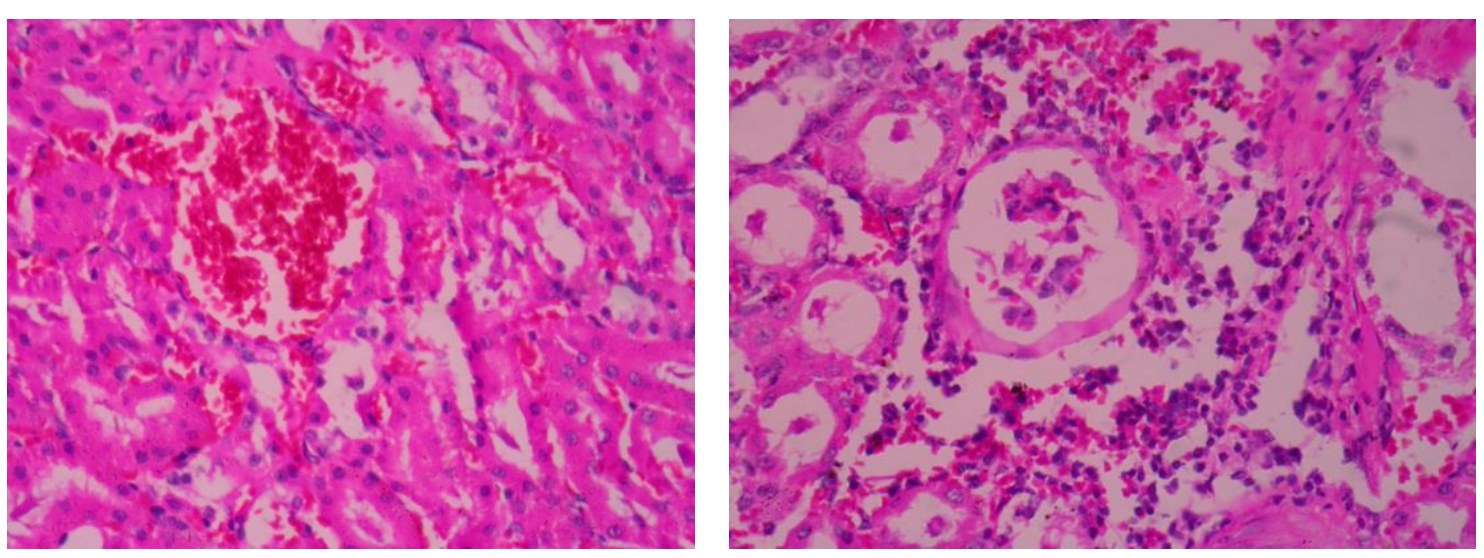
Group C - Katakabeeja Yoga (40 X)

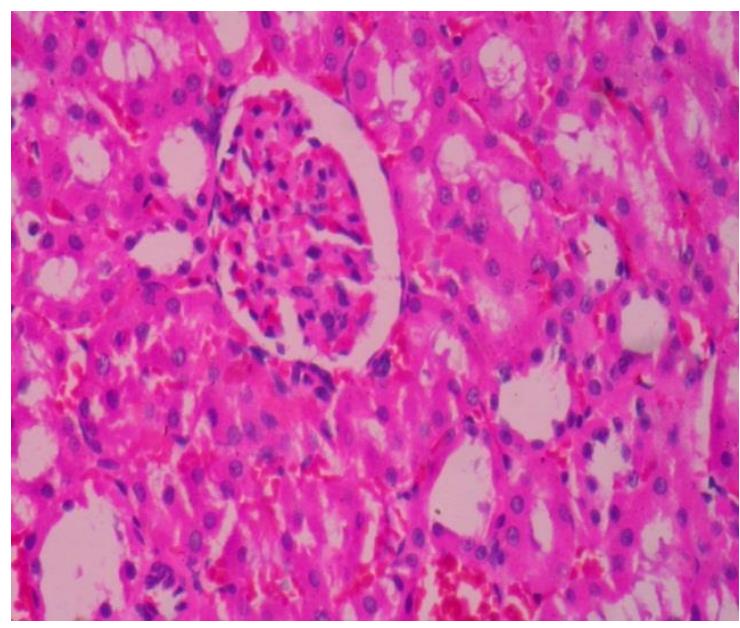

\section{DISCUSSION}

Katakabeeja yoga is a compound preparation that is mentioned in the context of PramehaChikitsa ${ }^{[5]}$. This preparation mainly contains Katakabeeja, Takra and Madhu.

Katakabeeja has been in detail researched in relevance to Antidiabetic activity ${ }^{[8]}$, Antioxidant ${ }^{[9]}$, Antiinflammatory activity ${ }^{[10]}$, Analgesic activity ${ }^{[11]}$, Antinociceptive and antipyretic effect of seeds ${ }^{[12]}$, Hepatoprotective and antioxidant actions ${ }^{[13]}$, and Diuretic activity of seeds ${ }^{[14]}$.

Aqueous and Alcoholic extract of Katakabeeja contains Reducing sugars, Steroids, Cardiac and Saponin glycosides, Alkaloids, Tannins, Calcium, Sodium, Iron, and Nitrates. Among these Saponin might have reduced the inflammation due to Anti-inflammatory activity ${ }^{[\mathbf{1 5}]}$, Tannins have haemostatic properties, anti-inflammatory activity (C. Hartisch et al), Calcium - Helps for clotting mechanism and stability of the cell membrane ${ }^{[16]}$. Nitrates - The most prominent action is relaxing vascular smooth muscles and redistribution of blood flow to an ischemic area ${ }^{[17]}$.

\section{URINE OUTPUT:}

A significant difference $(p<0.005)$ was evidenced in Urine Output between the groups from $1^{\text {st }}$ day, $8^{\text {th }}$ day till day $15^{\text {th }}$ respectively between the Normal group $\mathbf{( 4 . 4 6 7} \pm \mathbf{1 . 6 3 8}, \mathbf{5 . 3 6 7} \pm \mathbf{1 . 2 7 4}$, and $6.783 \pm \mathbf{0 . 8 9 9 8})$ and Aspirin group $(\mathbf{3 . 4 0 0} \pm \mathbf{0 . 9 7 1 6}, \mathbf{3 . 3 8 3} \pm \mathbf{0 . 8 5 6 5}$ and $2.100 \pm 1.661)$ and also between Aspirin group $(3.400 \pm 0.9716,3.383 \pm 0.8565$ and $2.100 \pm 1.661)$

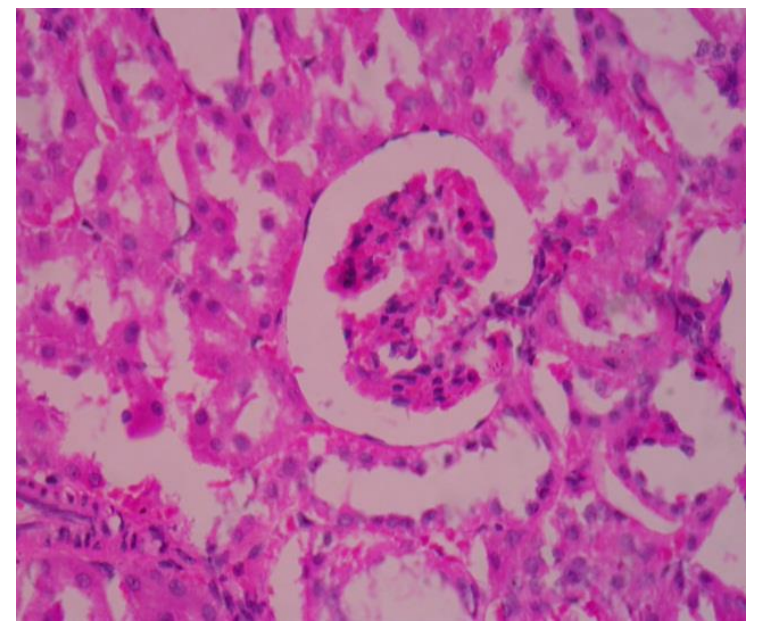

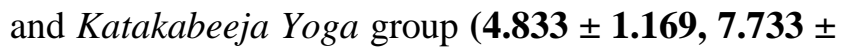
1.108 and $6.950 \pm 3.505)$. When compared between the Normal group $(4.467 \pm 1.638,5.367 \pm 1.274$, and $\mathbf{6 . 7 8 3} \pm \mathbf{0 . 8 9 9 8}$ ) and Katakabeeja Yoga group (4.833 $\pm 1.169,7.733 \pm 1.108$ and $6.950 \pm 3.505)$ the volume of Urine Output is the same which confirms the diuretic activity of Katakabeeja. The increase of cations in the urine on treatment with Katakabeeja (Strychnos Potatorum Linn). This effect supports the use of the Katakabeeja (Strychnos Potatorum. Linn) as a diuretic in folk remedies ${ }^{[14]}$.

\section{UREA:}

The Katakabeeja Yoga treated group has decreased in the Urea level compared with Aspirin treated group (43.28 \pm 3.862), when compared with the Katakabeeja Yoga group \&Normal group $(49.47 \pm \mathbf{4 . 0 2 4})$ it shows significance. The Aspirin group has raised the Urea level compared with the Normal group with (37.44 $\pm \mathbf{2 . 8 3 4 )}$. Because Katakabeeja has nitrates ${ }^{[17]}$ and antioxidant ${ }^{[9]}$, anti-inflammatory activity ${ }^{[10]}$.

\section{CREATININE:}

The Katakabeeja Yoga treated group has decreased in a higher Creatinine level compared with Aspirin treated group $(\mathbf{1 . 1 5 3} \pm \mathbf{0 . 1 4 2 8})$, when compared with the Katakabeeja Yoga group \&Normal group (1.758 $\pm \mathbf{0 . 2 1 5 7}$ ) it shows significance. The Aspirin group has raised the Creatinine level compared with the Normal group with $(\mathbf{0 . 9 5 2 8} \pm \mathbf{0 . 0 8 9})$. Because $\mathrm{Ka}$ takabeeja has nitrates ${ }^{[17]}$ and antioxidant ${ }^{[9]}$, antiinflammatory activity ${ }^{[10]}$. 


\section{Histopathological Reports: -}

KIDNEY: Tubular congestion, peritubular inflammation, Tubular necrosis in the Kidney showed more damage in the Aspirin group (+++) when compared to the Katakabeeja Yoga group (++). Cytoplasmic vacuole, glomerular congestion, interstitial haemorrhage showed mild damage in the Aspirin group (++) when compared to the Katakabeeja group (+). Interstitial oedema, widening of Bowmen space (+) but is not present in Katakabeeja Yoga group.

\section{CONCLUSION}

Katakabeeja Yoga has significantly increased Urine output and reduced Sr. Urea \& Sr. Creatinine. The serological and Histopathological changes show that the Katakabeeja Yoga has got protective effect against Aspirin-induced nephrotoxicity in Wistar rats. There was no significant change in the levels of Serum Potassium, Sodium, and Chloride.

\section{ACKNOWLEDGEMENT}

KLEU`s Shri B M Kankanawadi Ayurveda Mahavidyalaya and Research Center, Belagavi-590003

\section{REFERENCES}

1. A Review on Medicinal Plants for Nephroprotective Activity; Mohanalakshmi S, UshaKiran Reddy T, Sandhya Rani KS; Asian Journal of Pharmaceutical and Clinical Research.

2. $\mathrm{Li} \mathrm{Z}, \mathrm{Wu}$ J, Delo CJ.RNA damage and surveillance under oxidative stress, IUMB Life.2006 Oct,58(10):581-8.

3. Neha Jain, Renu Shrivastava, Arun K Raghuwanshi and Vinoy K Shrivastava, Aspirin-induced changes in serum acp, alp, got, gpt, bilirubin and creatinine in correlation with histopathological changes in liver and kidney of female albino rat, International Journal of Applied Pharmaceutics, ISSA - 0975-7058, Vol 4, Issue $3,2012$.

4. Susruta, Sri dalhanachary, Susrutasamhita; choukhambha Sanskrit sansthan Varanasi; reprient edition 2012.

5. Vaidyalakshimipatisastri, Yogaratnakar, Choukhambha Publications, Delhi, seventh edition 2002, Prameha Chikitsa adhyaya page no.85.

6. Agnivesh, Carakasamhita, AcharyVidyadharShukla and Prof.RaviDattatripathi; Choukhambha Sanskrit Pratishthan Delhi, reprint edition 2007; Vol - I.
7. Rajvaidya, P. Shankar Dattagouda, Shankhanighantupratambhaga, choukhambhavidyabhavana Varanasi, reprint edition 2002, page no.143.

8. Dhasarathan P and Theriappan P, Evaluation of Antidiabetic activity of strychnospotatorum on alloxaninduced diabetic rats, journal of medicine and medical science vol-2(2) pp 670-674 Jan-2011.

9. Sanmugapriyaekambaram, Senthanilselvanperumal and Venkataraman Subramanian, Assessment of the in-vivo and in-vitro Antioxidant potential of Strychnos potatorumlinn. seed sin freund's adjuvant-induced arthritic rats.

10. Mallikarjuna et al. Analgesic and Anti-inflammatory activities of Strychnos potatorumLinn.f. Seeds extracts, pharmacology online 2:876-882(2010).

11. Mallikarjuna et al. Analgesic and anti-inflammatory activities of Strychnos potatorumLinn.f. Seeds extracts, pharmacology online 2:876-882(2010).

12. Sanmugapriya E and Venkataraman S, Antinociceptive and Antipyretic effects of Strychnos potatorum Linn. Seeds on experimental rats, international journal of pharmacology 6(5):681-685(2010).

13. E Shanmugapriya and S Venkataraman, studies on Hepatoprotective and Antioxidant actions of Strychnos potatorumLinn.seeds on $\mathrm{CCL}_{4}$ induced acute hepatic injury in experimental rats, J. Ethanopharmaco, 105:154-160(2006).

14. Biswas S, Murgesh T, Maiti K, Ghosh L, Pal M and Saha B P, study on the Diuretic activity of Strychnos potatorumLinn.seeda extract in albino rats, phytomedicine, 8(6):469-471(2001).

15. Praveen kumarashok, KumudUpadhyaya, Tannins are Astringent, Journals of pharmacognosy and phytochemistry; ISSN 2278 - 4136; ZDB - number; 2668735 - 5, IC Journal No. 8192; Vol - I; Issue - 3 .

16. K.D. Tripathi, Essential of medical pharmacology; Jaypee Brothers, medical publishers Pvt. Itd Delhi; $6^{\text {th }}$ edition; 2008, pp.325.

17. K.D. Tripathi, Essential of medical pharmacology; Jaypee Brothers, medical publishers Pvt. Itd Delhi; $6^{\text {th }}$ edition; 2008, pp.522 - 27.

\section{Source of Support: Nil \\ Conflict of Interest: None Declared}

How to cite this URL: Manohar S. Sarangi et al: Evaluation of Nephroprotective Activity Of Katakabeeja Yoga Against Aspirin-Induced Nephrotoxicity In Wistar Rats. International Ayurvedic Medical Journal \{online\} 2021 \{cited November 2021\} Available from: http://www.iamj.in/posts/images/upload/3208 3218.pdf 